\title{
NZNSEE PRESIDENT'S PAGE
}

It is my pleasure as your newly elected President to introduce myself. I am the Structural Engineering Group Leader at the Building Research Association of New Zealand (BRANZ) based at Judgeford, outside Wellington. I have been a member of the Management committee of the Society for the past 4 years and have now been honoured with the President's role. Members are probably aware that the Society's rules decree that the Presidential term is limited to two years, and from the experience of past presidents, this appears to be quite long enough.

I would like to thank your new editor, Les Megget, for this opportunity to provide a brief statement as to the current position of the Society and where I see us heading during my term as your President.

The issue foremost in the minds of your management committee is the $12^{\text {th }}$ World Conference on Earthquake Engineering to be held in Auckland in January 2000. This is a major event both for New Zealand and the South Pacific and must be expected to involve considerable effort on all members of the Society. At this stage the conference committee has been formed under the chairmanship of Professor Bob Park. Planning is coming together with the task of hosting over 1200 delegates and with over 1500 papers expected setting the scene for a challenging but rewarding conference. During these early stages, much of the work will be undertaken by the Conference Committee themselves, but as the time approaches members should expect to be called on for assistance either with technical programme or for support in other areas. Please be generous with your time and reap the rewards of a successful conference.

The Societies technical study groups remain an area of strength. Several are in progress at this time including

- the Earthquake Risk Building Study Group, convened by David Brunsdon, are now focusing on pre-1976 Earthquake Prone Buildings with the support of the Building Industry Authority;

- the Industrial Plant Study Group, convened by Barry Davidson, has a positive endeavour to progress this group over the forthcoming year;

- the Storage Tanks Study Group is convened by Rob Jury and is looking towards developing a guide as to the seismic design of storage tanks as a supplement to the Red Book;
- the Post Earthquake Structural Response Study Group convened by Andrew Charleson has made considerable progress with its first phase of work and has distributed a to each Territorial Local Authority for comment as to how this work may be integrated into the TA's response plans;

- the Society also has taken an initiative to prepare a position paper on the need for Integrated Planning for Earthquake Preparedness during ' 96 which has been taken up by the secretary for Civil Defence and Internal Affairs and is being referenced by officials looking into the formulation of the Ministry of Emergency Management.

These Study Groups are a very effective way of bring the Societies collective expertise together to focus on topics of current interest and result in reports which are of direct and practical relevance to members. My thanks to each of the Study Group Convenors and to all members actively participating in these areas of development.

Maintaining public awareness of earthquakes and mitigation measures remains a clear focus of the Society and is expected to remain so over the forthcoming period. Planning is under way for our next annual conference (March 27/29 at Wairakei)

\section{Andrew King}

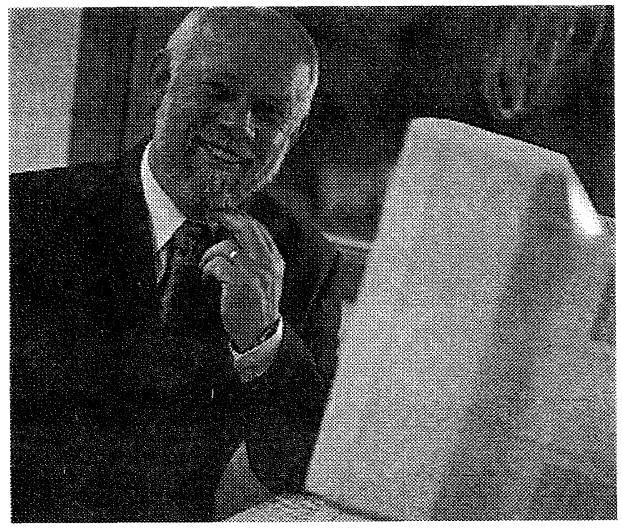

